\title{
The impact of angling experience on the efficiency of float fishing using different hook types
}

\author{
Tomasz K. Czarkowski, Andrzej Kapusta
}

Received - 08 November 2018/Accepted - 16 January 2019. Published online: 31 March 2019; Inland Fisheries Institute in Olsztyn, Poland Citation: Czarkowski T.K., Kapusta A. 2019 - The impact of angling experience on the efficiency of float fishing using different hook types Fish. Aquat. Life 27: 41-46.

\begin{abstract}
The aim of the study was to compare the catch efficiency of novice and experienced anglers float fishing with different hook types. The mortality of fish that were caught and released was determined based on the experience of the angler and the type of hook used. The mean catch rates of the experienced angler was 46.7 fish per hour, while that of the novice angler was 33.7 fish per hour. The landing efficiency of fish using hooks with micro-barbs was higher than that with barbless hooks. Angling experience had a significant impact on the mean time required to unhook caught fish and also on the mortality of the fish released. The lowest mortality was noted in fish caught by experienced anglers fishing with barbless hooks. The results of the study suggest that angling experience does not have a great impact on parameters characterizing the quality of angling catches. The efficiency of float fishing performed by novice and experienced anglers was similar. Differences were noted in the time required to unhook the fish and in the mortality of the fish released.
\end{abstract}

Keywords: catch-and-release, survival, mortality, angling

\footnotetext{
T.K. Czarkowski [ $\left.\square^{\circ}\right]$

Department of Fisheries Bioeconomics, Inland Fisheries Institute ul. Oczapowskiego 10, 10-719 Olsztyn, Poland

e-mail: t.czarkowski@w-modr.pl

Present address: Polish Angling Association, ul. Bałtycka 2,

11-041 Olsztyn, Poland

A. Kapusta

Department of Ichthyology, Hydrobiology and Aquatic Ecology,

Inland Fisheries Institute, Olsztyn, Poland
}

\section{Introduction}

Recreational angling catches in freshwaters are a key form of exploiting the fish resources of inland waters (Arlinghaus and Cooke 2009, Cowx 2015, Cooke et al. 2018). In the context of recreational angling, catch efficiency is a significant question (Prince et al. 2002, Cooke and Suski 2004, Rapp et al. 2008), but increasingly significant issues are those of mortality, injury, and the welfare of fish returned to waters in catch-and-release (C\&R) angling (Brownscombe et al. 2017, Danylchuk et al. 2018). C\&R is becoming increasingly popular in many countries (Freire et al. 2012, Brownscombe et al. 2017). In Poland, more than $70 \%$ of anglers practice C $\&$ R, of these $55.3 \%$ declare that they often release caught fish, while $15.2 \%$ of them always do (Czarkowski et al. 2018).

The type of gears used had a great impact on the mortality and the occurrence of wounds in the fish caught and released (Bartholomew and Bohnsack 2005, Brownscombe et al. 2017), which is why hook size and construction is important (Rapp et al. 2008, Ateşşahin et al. 2015, Bergmann et al. 2014, Garner et al. 2016). Simultaneously, they have a significant impact on angling efficiency, including on the hooking and landing efficiency (Prince et al. 2002, Cooke and Suski 2004, Rapp et al. 2008, Alós et al. 2009). Hook and bait types and sizes can impact the welfare 
and mortality of released fish (Meka 2004, Rapp et al. 2008, Stålhammar et al. 2012) and the time required to remove hooks and the overall air exposure time of the fish (Cooke et al. 2001, Arlinghaus et al. 2008). Angler experience is also recognized as a factor that impacts angling efficiency (Heerman et al. 2013), fish injury, and mortality (Dunmall et al. 2001, Meka 2004). The degree of awareness among Polish anglers about these issues is insufficient (Suryn and Biernaczyk 2017), which is why an experimental study was conducted with the aim of comparing the angling efficiency of experienced and novice anglers using different types of hooks used in float fishing, which is a popular method among Polish anglers. Simultaneously, the mortality of fish that were caught and released was determined as it depended on the experience of the angler and the type of hook used.

\section{Materials and methods}

The experimental catches were conducted on June 12-13, 2017, in Lake Kalwa in northeastern Poland. The catches were made by two anglers: one had twenty-five years of experience, while the second had no experience and was angling for the first time during the study, although he had been given basic angling instruction before angling. The two anglers fished next to each other at the same fishing grounds. The anglers were supplied with identical angling gear and tackle. Catches were performed with $500 \mathrm{~cm}$ poles (whip type). The gear comprised a mainline (diameter of $0.12 \mathrm{~mm}$ ) and a hooklength (diameter of $0.10 \mathrm{~mm}$ ) to which the hook was attached. A float with $1.5 \mathrm{~g}$ resistance and a lead sinker were placed on the mainline. Both of the anglers used two types of J-hooks: Drennan Silverfish Maggot Barbless and Drennan Red Maggot Micro Barbed (both 14 and 20 size). Maggots were used as bait. The anglers fished with the same type of hooks in the same place at the same time.

All the fish caught were classified to the species level and recorded. The anatomical location of hooking was also recorded for each fish (Alós et al. 2009). These were classified as shallow (non-critical), including the upper jaw, lower jaw, corner of the mouth, and externally on the body (Arlinghaus et al. 2008), or deep (critical), which were confirmed when a hook removal tool was required to remove them, including from the deep locations of the palate posterior to the eye line but anterior to the pharyngeal teeth (in cyprinids) and the esophagus (in perch) (Rapp et al. 2008, Garner et al. 2016). Any fish bleeding observed was also recorded. Total length and the amount of time the fish were exposed to the air were also recorded $( \pm 0.1 \mathrm{~s})$. Following these procedures, the fish were placed in large fish cages (length $300 \mathrm{~cm}$, diameter $50 \mathrm{~cm}$, mesh size $6 \mathrm{~mm}$ ) submerged in the water. Next, the occurrence of initial mortality, the ability to maintain balance, and respiratory movements were determined. After $6 \mathrm{~h}$ of holding, mortality was determined again by observing whether the fish were still alive and behaving normally, swimming without losing balance, and exhibiting respiratory movements. Then, all the fish were removed from the cages, sorted by species, counted, and measured (total length $\pm 1 \mathrm{~mm}$ ). This data was used to determine the efficiency of the catches expressed as catch rates giving the number and weight of the fish caught in one hour by one angler. The number of fish that were hooked but escaped during landing was also recorded. Based on this the landing efficiency was determined and was expressed as the percentage share of fish (\%), which, after hooking, were landed (number of fish landed/number of fish hooked) (Prince et al. 2002).

\section{Results and Discussion}

During the study 322 fish were caught with a total weight of 10,261 $\mathrm{g}$ belonging to six species, including 148 white bream (Blicca bjoerkna (L.)), 68 roach (Rutilus rutilus (L.)), 64 rudd (Scardinius erythrophthalmus (L.)), 38 common bleak (Alburnus alburnus (L.)), 3 perch (Perca fluviatilis L.), and 1 
Table 1

Summary of angling efficiency of experienced and novice anglers. CPUE expressed in number and weight of fish caught per hour. Landing efficiency is the proportion between the number of fish hooked and the number landed. Total length (TL \pm SD), body weight (BW)

\begin{tabular}{|c|c|c|c|c|c|c|c|}
\hline \multirow[b]{2}{*}{ Hook type } & \multirow[b]{2}{*}{$\mathrm{N}$} & \multirow[b]{2}{*}{ Weight $(\mathrm{g})$} & \multicolumn{2}{|l|}{ Catch rates } & \multirow[b]{2}{*}{ Landing efficiency (\%) } & \multirow[b]{2}{*}{ TL $(\mathrm{cm})$} & \multirow[b]{2}{*}{ BW (g) } \\
\hline & & & $\left(\right.$ fish hour $^{-1}$ ) & $\left(\right.$ g hour $\left.^{-1}\right)$ & & & \\
\hline \multicolumn{8}{|c|}{ Experienced angler } \\
\hline barbed & 97 & 3002 & 48.5 & 1501.0 & 85.8 & $14.1 \pm 1.86$ & 30.9 \\
\hline barbless & 90 & 3267 & 45.0 & 1633.5 & 82.6 & $14.5 \pm 2.41$ & 36.3 \\
\hline \multicolumn{8}{|c|}{ Novice angler } \\
\hline barbed & 61 & 1751 & 30.5 & 875.5 & 74.4 & $13.8 \pm 2.57$ & 28.7 \\
\hline barbless & 74 & 2241 & 37.0 & 1120.5 & 71.2 & $13.5 \pm 2.65$ & 30.3 \\
\hline
\end{tabular}

Table 2

Percentage of fish hooked in various anatomical locations in relation to hook type and angler experience. Values in parentheses are the numbers of fish captured

\begin{tabular}{llllll}
\hline \hline \multirow{2}{*}{ Hook type } & \multicolumn{2}{l}{ Non-critical hooking location } & & \\
\cline { 2 - 3 } & Upper jaw & Lower jaw & Corner of mouth & Internal & Critical hooking location \\
\hline \hline $\begin{array}{l}\text { Experienced angler } \\
\quad \text { barbed }\end{array}$ & $46.4(45)$ & $13.4(13)$ & $27.8(27)$ & $2.1(2)$ & $10.3(10)$ \\
$\quad$ barbless & $41.1(37)$ & $13.3(12)$ & $24.5(22)$ & $2.2(2)$ & $18.9(17)$ \\
$\begin{array}{l}\text { Novice angler } \\
\text { barbed }\end{array}$ & & & & & \\
$\quad$ barbless & $42.1(24)$ & $24.6(14)$ & $24.6(14)$ & $1.7(1)$ & $7.0(4)$ \\
\hline \hline
\end{tabular}

common bream (Abramis brama (L.)). The fish caught were generally small (Table 1 ). The experienced angler caught slightly larger fish in comparison to those caught by the novice angler, taking into consideration the hook type used (two-way ANOVA, $\mathrm{F}=1.34, \mathrm{df}=318, \mathrm{P}=0.247)$. The overall mean catch rates was 40.2 fish $\mathrm{h}^{-1}$ angler ${ }^{-1}$ and 1,282.6 $\mathrm{g}$ $\mathrm{h}^{-1}$ angler ${ }^{-1}$. Small fish dominated in catches made with similar methods (Smith 2002); however, the mean catch rates confirmed in the present study was decidedly higher than that in the UK of 13.4 fish $\mathrm{h}^{-1}$ angler $^{-1}$ and $128.5 \mathrm{~g} \mathrm{~h}^{-1}$ angler $^{-1}$ (Smith 2002). Despite the experienced angler generally catching more fish of a greater weight (Table 1), angling experience and hook type did not have a statistically significant impact on the catch rates (test $\chi^{2}$ with Yates's correction $=1.15, \mathrm{P}=0.284)$. Heerman et al. (2013) confirmed a dependence between catch rates and the experience of anglers in perch fishing in German lakes, but Czarkowski et al. (2018) did not find this correlation in a survey study of Polish anglers.

The landing efficiency ranged from $71.2 \%$ for novice anglers fishing with barbless hooks to $85.8 \%$ for experienced anglers fishing with micro-barbed hooks (Table 1). As anticipated (Meka 2004, Alós et al. 2008), landing efficiency with micro-barbed hooks was higher than with barbless hooks (Table 1). Most of the fish caught during the study were hooked on the upper jaw (Table 2). Overall, the hooking location in areas considered non-critical ranged from 95.9 to $98.3 \%$. Aside from the most frequently occurring hooking location in the upper jaw, hooking in the corner of the mouth and in the lower jaw was fairly common, while external hooking was the least common. Rapp et al. (2008) confirmed that most carp (Cyprinus carpio L.) were hooked in the lower jaw or 
Table 3

Exposure time (mean \pm SD) and percentage of fish in which bleeding was observed and mortality after being caught by an experienced or a novice angler

\begin{tabular}{lllll}
\hline \hline Angler & Hook type & Mean air exposure time (s) & Bleeding (\%) & Mortality within 6 h (\%) \\
\hline \hline Experienced angler & barbed & $9.4 \pm 5.28$ & 12.4 & 7.2 \\
& barbless & $9.8 \pm 10.69$ & 11.1 & 1.1 \\
Novice angler & barbed & $13.7 \pm 10.11$ & 8.2 & 9.8 \\
& barbless & $13.3 \pm 8.67$ & 4.1 & 4.0 \\
\hline \hline
\end{tabular}

in the corner of the mouth, and critical deep hooking did not occur. Potentially dangerous, deep hooking occurred more frequently among the fish caught by experienced rather than novice anglers (Table 2). A similar phenomenon was observed by Dunmall et al. (2001). The type of hook used did not influence hooking location in fish caught by experienced anglers (test $\chi^{2}=5.04, \mathrm{P}=0.282$ ), but among novice anglers hook type influenced hooking location and the fish caught (test $\chi^{2}=69.13, \mathrm{P}<0.05$ ).

Barbless hooks reduce the time required to unhook fish, which is why they are required at many C\&R fishing grounds (Cooke et al. 2001, Brownscombe et al. 2017). The time required to unhook fish depended on hooking location (Fig. 1). Experienced anglers were able to unhook fish hooked in the upper or lower jaw or the corner of the mouth the fastest, while it took them the longest time to unhook fish that had been hooked deeply (ANOVA, $\mathrm{F}=47.53$, $\mathrm{df}=$ $180, \mathrm{P}<0.05)$. Novice anglers needed the most time to remove hooks from fish that had been hooked deeply or on the outside of the mouth (ANOVA, $\mathrm{F}=16.96, \mathrm{df}=123, \mathrm{P}<0.05)$. Arlinghaus et al. (2008) came to similar conclusions in studies of pike, Esox lucius L.; the time required to remove hooks was a function of hooking location, and hook removal was decidedly longer when the hooking location was deep. Angling experience had a significant impact on the mean time the fish were exposed to the air (Table 3; two-way ANOVA, $\mathrm{F}=15.57$, df $=315, \mathrm{P}<0.05)$, but what was surprising was that this was not associated with hook type (two-way ANOVA, $\mathrm{F}=0,01$, $\mathrm{df}=315, \mathrm{P}=$
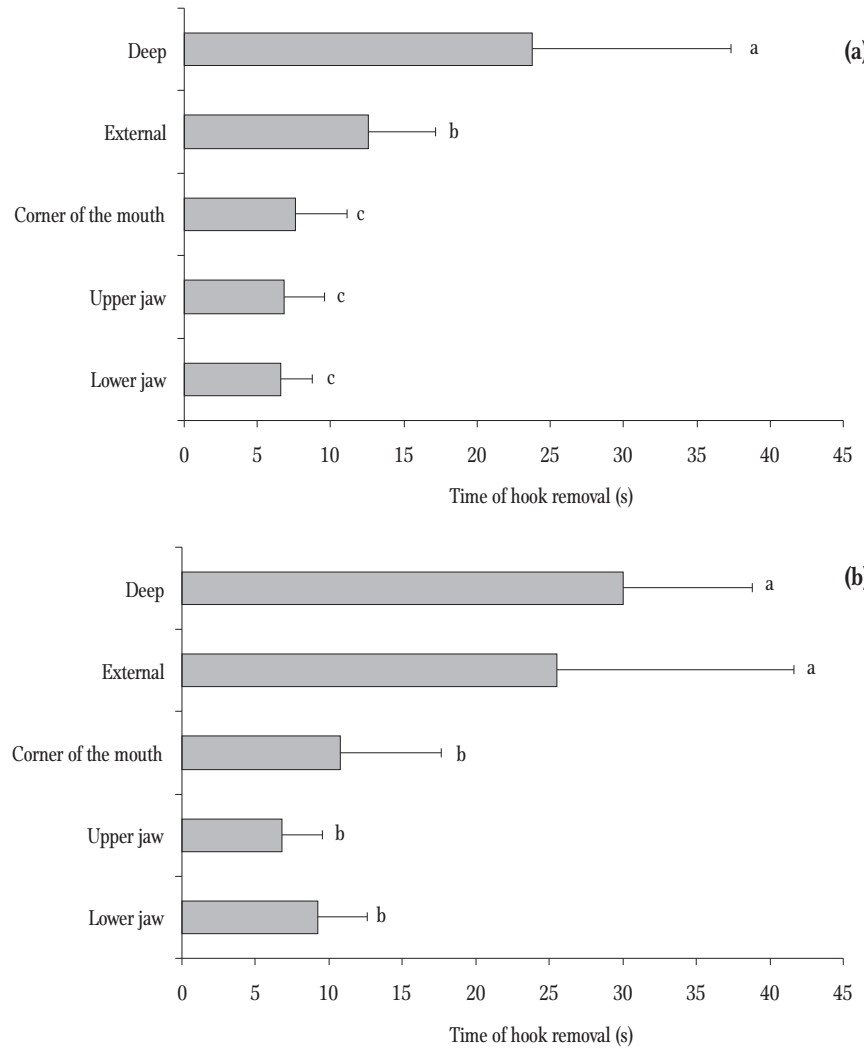

Figure 1. Mean ( \pm SD) time required to unhook fish (s) by experienced (a) and novice (b) anglers depending on anatomical hooking location. Mean values marked with different letter indexes differ significantly statistically $(\mathrm{P}<0.05)$.

\section{(a)}

(b)

0,975). Perhaps hooks with micro-barbs are sufficient for fish hooked, but just as easy to unhook as barbless hooks.

Bleeding in fish after they were unhooked was noted rarely, but it was noted more frequently with experienced anglers (Table 3). Bleeding was noted more frequently with micro-barbed hooks in comparison to barbless hooks. However, Meka (2004) did not observe any differences between the 
frequency of bleeding when using barbed and barbless hooks. Catch mortality observed for $6 \mathrm{~h}$ was low and ranged from $1.1 \%$ when experienced anglers used barbless hooks to $9.8 \%$ when novice anglers used micro-barbed hooks (Table 3). Generally, lower mortality was noted among fish caught by experienced anglers and when barbless hooks were used (Table 3). Dunmall et al. (2001) found no dependence between short-term mortality and angler experience. Regarding hook type, however, few studies to date have confirmed unequivocally that mortality is lower when fish are caught with barbless hooks in C\&R angling (Bartholomew and Bohnsack 2005, Brownscombe et al. 2017).

The results of this study suggest that angler experience does not have a great impact on the parameters characterizing the quality of angling catches. The float fishing catch efficiency of novice anglers was similar to that of experienced anglers. Differences were noted in the time required to unhook fish and also in the mortality of the fish released.

Acknowledgements. We thank Jakub Pyka and Bartosz Czarnecki for great support in this study, and reviewers for excellent feedback. Funding for this study was provided by the Inland Fisheries Institute, Olsztyn, Poland.

Author contributions. T.K.C and A.K. designed the study, T.K.C. sampled the specimens for the study, T.K.C and A.K. performed the analyses and wrote the manuscript.

\section{References}

Alós J., Palmer M., Grau A.M., Deudero S., 2008 - Effects of hook size and barbless hooks on hooking injury, catch per unit effort, and fish size in a mixed-species recreational fishery in the western Mediterranean Sea - ICES J. Mar. Sci. 65: 899-905.

Alós J., Mateu-Vicens G., Palmer M., Grau A.M., Cabanellas-Reboredo M., Box A. 2009 - Performance of circle hooks in a mixed-species recreational fishery - J. Appl. Ichthyol. 25: 565-570.

Arlinghaus R., Cooke S.J. 2009 - Recreational fisheries: socioeconomic importance, conservation issues and management challenges - In: Recreational Hunting,
Conservation and Rural Livelihoods: Science and Practice (Eds) B. Dickson, J. Hutton, M.W. Adams, Blackwell Publishing Oxford: 39-58.

Arlinghaus R., Klefoth T., Kobler A., Cooke S.J. 2008 - Size selectivity, injury, handling time, and determinants of initial hooking mortality in recreational angling for northern pike: the influence of type and size of bait - N. Am. J. Fish. Manage. 28: 123-134.

Ateşşahin T., Duman E., Cilbiz M. 2015 - Selectivity and catch efficiency of three spinner hook sizes in angling for Rainbow trout (Oncorhynchus mykiss Walbaum, 1792) in Karakaya Dam Lake (Eastern Turkey) - Turk. J. Fish. Aquat. Sci. 15: 851-859.

Bartholomew A., Bohnsack J.A. 2005 - A review of catch-and-release angling mortality with implications for no-take reserves - Rev. Fish Biol. Fish. 15: 129-154.

Bergmann C., Driggers III W.B., Hoffmayer E.R., Campbell M.D., Pellegrin G. 2014 - Effects of appendaged circle hook use on catch rates and deep hooking of black sea bass in a recreational fishery - N. Am. J. Fish. Manag. 34: 1199-1203.

Brownscombe J.W., Danylchuk A.J., Chapman J.M., Gutowsky L.F.G., Cooke S.J. 2017 - Best practices for catch-and-release recreational fisheries - angling tools and tactics - Fish. Res. 186: 693-705.

Cooke S.J., Philipp D.P., Dunmall K.M., Schreer J.F. 2001 The influence of terminal tackle on injury, handling time, and cardiac disturbance of rock bass - N. Am J. Fish. Manag. 21: 333-342.

Cooke S.J., Suski C.D. 2004 - Are circle hooks an effective tool for conserving marine and freshwater recreational catch-and-release fisheries? - Aquatic Conserv: Mar. Freshw. Ecosyst. 14: 299-326.

Cooke S.J., Twardek W.M., Lennox, R.J., Zoldero A.J., Bower S.D., Gutowsky L.F.G., Danylchuk A.J., Arlinghaus R., Beard D. 2018 - The nexus of fun and nutrition: Recreational fishing is also about food - Fish Fish. 19: 201-224.

Cowx I.G. 2015 - Characterisation of inland fisheries in Europe - Fish. Manage. Ecol. 22: 78-87.

Czarkowski T.K., Wołos A., Kapusta A., Kupren K., Mickiewicz M. 2018 - Changes in Polish angling over the past 40 years: Catches, opinions, preferences and socioeconomic aspects of contemporary anglers - In: Fisheries and angling enterprises in 2017 (Eds) M. Mickiewicz, A. Wołos, Wyd. IRS, Olsztyn: 99-121 (in Polish).

Danylchuk A.J., Clark Danylchuk S., Kosiarski A., Cooke S.J, Huskey B. 2018 - Keepemwet Fishing-An emerging social brand for disseminating best practices for catch-and-release in recreational fisheries - Fish. Res. 205: 52-56.

Dunmall K.M., Cooke S.J., Schreer J.F., McKinley R.S. 2001 - The effect of scented lures on the hooking injury and 
mortality of smallmouth bass caught by novice and experienced anglers - N. Am. J. Fish. Manage. 21: 242-248.

Freire K.M., Machado M.L., Crepaldi D. 2012 - Overview of inland recreational fisheries in Brazil - Fisheries 37: 484-494.

Garner S.B., Dahl K.A., Patterson W.F. III. 2016 - Hook performance and selectivity of Eurasian perch, Perca fluviatilis (Linnaeus, 1758) in the Åland Archipelago, Finland - J. Appl. Ichthyol. 32: 1065-1071.

Heermann L., Emmrich M., Heynen M., Dorow M., König U., Borcherding J., Arlinghaus R. 2013 - Explaining recreational angling catch rates of Eurasian perch, Perca fluviatilis: the role of natural and fishing-related environmental factors - Fish. Manage. Ecol. 20: 187-200.

Meka J.M. 2004 - The influence of hook type, angler experience, and fish size on injury rates and the duration of capture in an Alaskan catch-and-release rainbow trout fishery - N. Am. J. Fish. Manage. 24: 1309-1321.

Prince E.D., Ortiz M., Venizelos A. 2002 - A comparison of circle hook and "J" hook performance in recreational catch-and-release fisheries for billfish - Am. Fish. Soc. Symp. 30: 66-79.

Rapp T., Cooke S.J., Arlinghaus R. 2008 - Exploitation of specialised fisheries resources: The importance of hook size in recreational angling for large common carp (Cyprinus carpio L.) - Fish. Res. 94: 79-83.

Smith P.A. 2002 - The relationship between stock and catch and the effect of bait on catch as determined for a UK recreational catch and release fishery - Fish. Manage. Ecol. 9: 261-266.

Stålhammar M., Linderfalk R., Brönmark C., Arlinghaus R., Nilsson P.A. 2012 - The impact of catch-and-release on the foraging behaviour of pike (Esox lucius) when released alone or into groups - Fish. Res. 125-126: 51-56.

Suryn J., Biernaczyk M. 2017 - Pike (Esox lucius L.) angling catches in the waters of Roslagen Archipelago, Sweden Komun. Ryb. 4: 8-12 (in Polish). 